\title{
複数設計点法を利用した飛しょう体のオンライン誘導則*1 Online Guidance Law of Missile Using Multiple Design Point Method
}

\author{
山 岡 清 志*2 \\ Seiji YamaokA and Seiya Ueno
}

Key Words : Guidance and Control, Optimal Control, Missiles

\begin{abstract}
This paper deals with design procedure of online guidance law for future missiles that are required to have agile maneuverability. For the purpose, the authors propose to mount high power side-thrusters on a missile. The guidance law for such missiles is discussed from a point of view of optimal control theory in this paper. Minimum time problem is solved for the approximated system. It is derived that bang-bang control is optimal input from the necessary conditions of optimal solution. Feedback guidance without iterative calculation is useful for actual systems. Multiple design point method is applied to design feedback gains and feedforward inputs of the guidance law. The numerical results show the good performance of the proposed guidance law.
\end{abstract}

1. は じめ に

将来の飛しょう体は高機動·速応性が必要となることが予 想されるが , 従来の後翼操舵方式ではこれに対処すること が困難である . 近年の飛しょう体誘導の研究では, 光のよ うな問題に対処するために樣々な研究が行われている.飛 しょう体誘導制御系の研究は, 質点系の最適制御による最 短時間問題などの誘導や剛体系の姿勢制御等 ${ }^{1 ~ 3)}$ が行われ ている．弚の運動の表現は，過去の文献 4)に示すように， 3 次元空間で飛しょう体運動を表現した事例がある. 3 次元 空間内の非線形運動方程式による最短時間問題を解いた誘 導系の最適制御の研究である. また，線形な運動方程式に より，主として姿勢制御を行った事例もある ${ }^{5,6)}$.しかし， ピッチ系, ロール/ヨー系の運動が別々に表現することが可 能であることより，飛しょう体運動を 2 次元平面で表現し た研究もある7).これらは, 垂直面内での運動を扱った非 線形な誘導系の最適制御の研究である.これらの研究事例 のように，比較的簡単な運動方程式で表現することにより， 高機動な飛しょう体運動を表すことが可能である．本稿で は, 文献1) と同樣な問題を設定し, 短時間のマヌーバに対 するオンライン誘導則を最適制御の観点て設計することを 提案する.

サイドスラスタはメインスラスタとは異なる独立した推 力源を持っているため, 発射直後の低速域や高高度の大気 が希薄な領域でも使用可能であり，使用領域に制限がない． 一般的にサイドスラスタを用いた研究は, 衛星等で使われ

\footnotetext{
*1 (C) 2010 日本航空宇宙学会

平成 20 年 11 月 20 日, 2008 KSAS-JSASS Joint International Symposium on Aerospace Engineering において一部発表 . 平 成 20 年 11 月 12 日原稿受付

$* 2$ 横浜国立大学大学院環境情報学府

$* 3$ 横浜国立大学大学院環境情報研究院
}

ている液体燃料を使用し，On-Off 制御を行うものが知られ ている．また固体燃料を使用し，複数のスラスタによるイ ンパルス制御を行い誘導制御を行っているものもある.こ れらの事例は，飛しょう体への適用には，液体燃料スラス タでは貯蔵性及び安全性に問題があり, 機械機構が複雑に なる．また固体燃料スラスタは小型のロケットモータを機 体に多数配置しなければならず, 配置に制約がある。しか し，本稿で想定しているサイドスラスタは，推力を連続的 に制御できる非インパルス型である。これは, 貯蔵性及び 安全性に優れ，機構も比較的簡単である。

本稿は，この機敏な運動に有用であり，安全性等に優れ るサイドスラスタを用いた飛しょう体誘導制御系設計を目 指すため，最適制御を用いた新たな設計手法を提案する。 一般に最適制御は繰り返し計算を行って最適入力を求める. しかし，これでは異なる境界条件には新しく計算が必要と なり，実装に適していない，光れに対して，提案する設計 手法は, フィードバックにより最適入力を求めるため，機 上での繰り返し計算を必要としない誘導則が導かれる. 対 象とする問題の最適入力は bang-bang 入力であることか導 かれるため, 入力の切換時刻を与える切換関数をフィード バックで生成することを特徵とする.切換関数が初期条件 に対して連続的に变化する傾向を利用し, bang-bang 入力 の切換回数の変化にも柔軟に対応できる.フィードバック ゲイン等は, 複数の境界条件を同時に最適化する複数設計 点法を適用して求める誘導則の設計手法である.

この新たな手法の有効性を検証するとともに，従来型の 後翼操舵飛しょう体とサイドスラスタ搭載飛しょう体に適 用する，兰の結果を比較検討し，サイドスラスタ搭載の有 効性も明らかにする . 


\section{2. 飛しょう体モデル}

2.1 非線形飛しょう体モデル 飛しょう体の誘導制御は 数多くの研究事例 ${ }^{8)}$ があり, 線形運動方程式を用いた比例 航法などの誘導から，非線形運動方程式を用いた最適誘導 33 の事例など樣々である. 特に, 飛しょう体が中距離を飛行 する誘導には, 重量変化や空力特性の変化を考慮した非線 形運動方程式を用いることが必要となる。しかし, 本稿は 短時間のマヌーバにおける誘導則を導くことを目的として いるため, 誘導則の導出に線形運動方程式を扱うことが可 能である．ただし，飛しょう体の並進運動だけでなく回転 運動も考慮する必要がある. 谷の線形運動方程式を導くた めに, まずサイドスラスタを重心の前方に操舵翼を後方に 装備した非線形運動方程式を示す . 運動方程式に用いる座 標系と記号の定義を第 1 図に示す．これにより，垂直面内 の非線形運動方程式は, 以下で与えられる .

$$
\begin{aligned}
& \dot{V}=\left(T_{\mathrm{m}} \cos \alpha-T_{\mathrm{s}} \sin \alpha-D_{\mathrm{b}}-D_{\mathrm{r}}-m g \sin \gamma\right) / m \\
& \dot{\gamma}=\left(T_{\mathrm{m}} \sin \alpha+T_{\mathrm{s}} \cos \alpha+L_{\mathrm{b}}+L_{\mathrm{r}}-m g \cos \gamma\right) /(m V) \\
& \dot{q}=\left(T_{\mathrm{s}} l_{\mathrm{t}}+M_{\mathrm{b}}-L_{\mathrm{r}} l_{\mathrm{r}} \cos \alpha-D_{\mathrm{r}} l_{\mathrm{r}} \sin \alpha\right) / I \\
& \dot{x}=V \cos \gamma \\
& \dot{z}=V \sin \gamma \\
& \dot{\theta}=q
\end{aligned}
$$

ここで, 状態変数は速度 $V$, 経路角 $\gamma$, 姿勢角速度 $q$, 水 平方向距離 $x$, 垂直方向距離 $z$, 姿勢角 $\theta$ である.メイン スラスタ推力 $T_{\mathrm{m}}$ とサイドスラスタ推力 $T_{\mathrm{s}}$ は機体に固定さ れた方向に作用する. 空気力は速度に対する成分に分解し て定義し, 操舵翼が発生する揚力と抗力は $L_{\mathrm{r}}$ と $D_{\mathrm{r}}$, 兴の 他の胴体や固定翼が発生する揚力と抗力を $L_{\mathrm{b}}$ と $D_{\mathrm{b}}$ ，ピッ チングモーメントを $M_{\mathrm{b}}$ とする.なお， $L_{\mathrm{r}}$ と $D_{\mathrm{r}}$ は迎角 $\alpha$ と操舵翼舵角 $\delta_{\mathrm{r}}$ の関数で与えられ, 兴の他の空気力は迎 角の関数とする. サイドスラスタと操舵翼の位置は重心か らの距離 $l_{\mathrm{t}}$ と $l_{\mathrm{r}}$ で表わし，第 1 図に示す状態を正とする. その他の記号等は, 質量 $m$, 慣性モーメント $I$, 重力加速 度 $g$ である.

入力変数はサイドスラスタ推力 $T_{\mathrm{s}}$ と操舵翼舵角 $\delta_{\mathrm{r}}$ の 2

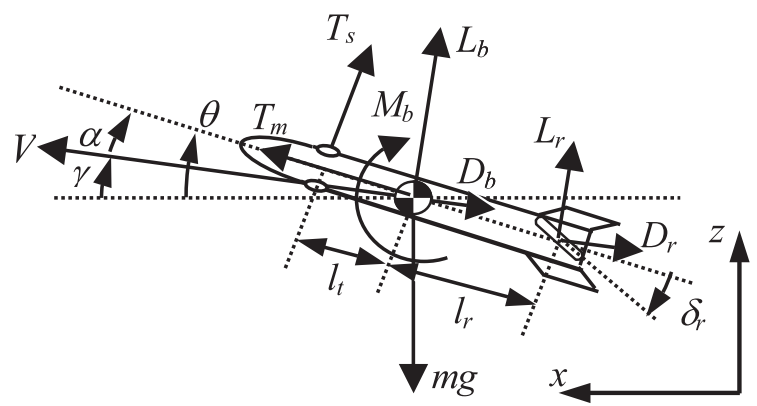

第 1 図 飛しょう体の状態变数等の定義
入力とする .ここで, このサイドスラスタは燃焼ガスを左 右に噴出し，弚の差をバルブで制御するタイプを想定する . 従って連続的にスラスタ推力を変更することが可能な非イ ンパルス型スラスタである.制御入力に関する制限は, 操 舵翼舵角とサイドスラスタ推力に与えられる .

$$
\begin{aligned}
& -\delta_{\max } \leq \delta_{\mathrm{r}} \leq \delta_{\max } \\
& -T_{\max } \leq T_{\mathrm{s}} \leq T_{\max }
\end{aligned}
$$

両者とも 0 を中心とした範囲に制限され, 乥れどれの最大 値は定数とする .

2.2 線形飛しょう体モデル 比較的長い距離を飛行す る飛しょう体では, 非線形運動方程式で表現することが必 要である. 光れに対して, 本稿は極短時間でのマヌーバ運 動を対象としているため, 質量の変化や速度の変化を無視 し, 運動は線形運動方程式で近似できる . 上記の非線形運 動方程式から水平定常飛行状態のまわりで状態変数を近似 し，以下の線形運動方程式を導くことができる ${ }^{9)}$.

$$
\begin{aligned}
& \dot{\gamma}=Z_{\alpha}(\theta-\gamma)+Z_{\delta} \delta_{\mathrm{r}}+Z_{\mathrm{T}} T_{\mathrm{s}} \\
& \dot{q}=M_{\alpha}(\theta-\gamma)+M_{\delta} \delta_{\mathrm{r}}+M_{\mathrm{T}} T_{\mathrm{s}} \\
& \dot{z}=V_{\mathrm{m}} \gamma \\
& \dot{\theta}=q
\end{aligned}
$$

ここで， $V_{\mathrm{m}}$ は定常速度であり， $M_{\alpha}$ 等の空力微係数はす べて定数となる.制御入力に関する制限として, 式 (7) と 式 (8) が与えられるとする.なお，一般に舵角角速度の制 限が考慮されているが, 本稿では省略する . 水平方向距離 は, 後に定義する最適制御問題で使用しないために, 省略 している。

\section{3. 最短時間経路変更問題}

3.1 問題の定義 本稿では, 終末誘導における短時間 の経路変更問題を対象としている. 直進していた飛しょう 体を $z$ 方向へ最短時間で経路を変更するマヌーバである. 飛しょう体運動方程式と初期条件及び各種制約条件で定義 されるシステムにおいて, 最短時間で状態変数を指定の条 件に導く最適解を見出す ${ }^{10,11)}$.

初期条件と終端条件を以下に定義する．

$$
\begin{aligned}
& \gamma(0)=q(0)=\theta(0)=0, \quad z(0)=Z_{0} \\
& \gamma\left(t_{\mathrm{f}}\right)=q\left(t_{\mathrm{f}}\right)=z\left(t_{\mathrm{f}}\right)=\theta\left(t_{\mathrm{f}}\right)=0
\end{aligned}
$$

ただし， $t_{\mathrm{f}}$ は終端時間である．最短時間問題であるから， 評価関数は次式で定義する.

$$
J=\int_{0}^{t_{\mathrm{f}}} \mathrm{d} t
$$

これにより，式 (9)〜 (12) の運動方程式 , 式 (13)，(14)の 境界条件と式 $(7),(8)$ の拘束条件を満たし, 式 (15) を最 小とするサイドスラスタ推力 $T_{\mathrm{s}}$ と操舵翼舵角 $\delta_{\mathrm{r}}$ を求める 問題として定義された . 
3.2 最適解の必要条件 数值的に解を求める前に最適 制御理論で導かれる必要条件を示す．まず, Hamiltonian は随伴変数 $\lambda$ と $\mu$ を導入して, 次式で定義される .

$$
H=L+\lambda^{\mathrm{T}} f+\mu^{\mathrm{T}} C
$$

$L$ は式 (15) の被積分関数,$f$ は式 $(9) \sim(12)$ の状態方程式 の右辺， $C$ は式 $(7)$, (8) の不等式拘束条件を $C \leq 0$ と記 述したときの関数である.

$$
C=\left(\begin{array}{c}
C_{1} \\
C_{2}
\end{array}\right)=\left(\begin{array}{c}
\delta_{\mathrm{r}}^{2}-\delta_{\max }^{2} \\
T_{\mathrm{s}}^{2}-T_{\max }^{2}
\end{array}\right)
$$

具体的にサイドスラスタ搭載飛しょう体の場合, Hamiltonian は以下である .

$$
\begin{aligned}
H= & 1+\lambda_{1}\left(Z_{\alpha}(\theta-\gamma)+Z_{\delta} \delta_{\mathrm{r}}+Z_{\mathrm{T}} T_{\mathrm{s}}\right) \\
& +\lambda_{2}\left(M_{\alpha}(\theta-\gamma)+M_{\delta} \delta_{\mathrm{r}}+M_{\mathrm{T}} T_{\mathrm{s}}\right) \\
& +\lambda_{3} V_{\mathrm{m}} \gamma+\lambda_{4} q \\
& +\mu_{1}\left(\delta_{\mathrm{r}}^{2}-\delta_{\max }^{2}\right)+\mu_{2}\left(T_{\mathrm{s}}^{2}-T_{\max }^{2}\right)
\end{aligned}
$$

これを用いれば, 必要条件から次式が導かれる.

$$
\begin{aligned}
& \partial H / \partial \delta_{\mathrm{r}}=\lambda_{1} Z_{\delta}+\lambda_{2} M_{\delta}+2 \mu_{1} \delta_{\mathrm{r}}=0 \\
& \partial H / \partial T_{\mathrm{s}}=\lambda_{1} Z_{\mathrm{T}}+\lambda_{2} M_{\mathrm{T}}+2 \mu_{2} T_{\mathrm{s}}=0
\end{aligned}
$$

不等式拘束条件にかかる随伴变数 $\mu_{i}$ は, 拘束条件か境界 $\left(C_{i}=0\right)$ のときは $\mu_{i}>0$ であり, 光の他 $\left(C_{i}<0\right)$ のとき は $\mu_{i}=0$ である . これより, 以下の切換関数を定義する.

$$
\begin{aligned}
& \sigma_{1}=\lambda_{1} Z_{\delta}+\lambda_{2} M_{\delta} \\
& \sigma_{2}=\lambda_{1} Z_{\mathrm{T}}+\lambda_{2} M_{\mathrm{T}}
\end{aligned}
$$

このとき最適入力は以下となる .

$$
\begin{aligned}
& \delta_{\mathrm{r}}= \begin{cases}\delta_{\max } & \left(\sigma_{1}<0\right) \\
\delta_{\text {int }} & \left(\sigma_{1}=0\right) \\
-\delta_{\max } & \left(\sigma_{1}>0\right)\end{cases} \\
& T_{\mathrm{s}}= \begin{cases}T_{\max } & \left(\sigma_{2}<0\right) \\
T_{\text {int }} & \left(\sigma_{2}=0\right) \\
-T_{\max } & \left(\sigma_{2}>0\right)\end{cases}
\end{aligned}
$$

$\delta_{\mathrm{int}}, T_{\mathrm{int}}$ は中間の入力であり，切換関数 $\sigma_{i}$ が有限時間の 間に 0 を維持するときに得られる特異入力である .

随伴変数の微分方程式は次式で与えられる.

$$
\begin{aligned}
& \dot{\lambda}_{1}=-\partial H / \partial \gamma=\lambda_{1} Z_{\alpha}+\lambda_{2} M_{\alpha}-\lambda_{3} V_{\mathrm{m}} \\
& \dot{\lambda}_{2}=-\partial H / \partial q=-\lambda_{4} \\
& \dot{\lambda}_{3}=-\partial H / \partial z=0 \\
& \dot{\lambda}_{4}=-\partial H / \partial \theta=-\lambda_{1} Z_{\alpha}-\lambda_{2} M_{\alpha}
\end{aligned}
$$

式 $(27)$ より $\lambda_{3}$ は定数であることがわかる . 従って , 次式 が導かれる。

$$
\lambda_{3}=\nu_{3}
$$

ただし， $\nu_{3}$ は末定乗数である．

最適解に特異入力が存在するかについて調べる . 特異入 力の判定には一般化された Legendre-Clebsch 条件 ${ }^{11)}$ がよ く用いられる.一般化された Legendre-Clebsch 条件は入 力を $u$ とすれば次式である .

$$
\frac{\partial}{\partial u}\left[\frac{\mathrm{d}^{2}}{\mathrm{~d} t^{2}}\left(\frac{\partial H}{\partial u}\right)^{\mathrm{T}}\right] \leq 0
$$

最適解が特異入力を用いる区間では，この不等式を満たす 必要がある.本稿で扱う問題の場合, 式 (19)，(20)より $\partial H / \partial u$ に含まれる変数は随伴変数のみである . 一方, 式 $(25) \sim(28)$ の随伴変数の微分方程式も変数は随伴変数のみ であり, 状態変数も入力変数も含まれていない . 式 (30) の 時間による 2 階微分には入力変数が含まれないことになる 従って，式 (30) は常に等号が成立することが導かれる．対 象とするシステムは, 特異入力を使用する可能性がある .

特異入力の存在について更に検証を重ねる . 切換関数が 0 を維持したときに特異入力が現れる．关の区間で切換関 数の時間微分は 0 となる. 切換関数を時間で微分して，随 伴変数の微分方程式を代入すれば, 時間微分が求められる.

操舵翼舵角の場合は, まず式 (21) を以下のように定義 する

$$
\sigma_{1}=\lambda_{1} Z_{\delta}+\lambda_{2} M_{\delta}=0
$$

式 (31) を微分し, 随伴変数の微分方程式を代入すると次の 式を得る .

$$
\dot{\sigma}_{1}=Z_{\alpha} Z_{\delta} \lambda_{1}+Z_{\delta} M_{\alpha} \lambda_{2}-V_{\mathrm{m}} Z_{\delta} \lambda_{3}-M_{\delta} \lambda_{4}=0
$$

ここで, 式 $(31)$ の変形 $\left\ulcorner\lambda_{1} Z_{\delta}=-\lambda_{2} M_{\delta}\right\lrcorner$ を式 $(32)$ の微 分に代入すると式 $(33)$ が得られる .

$$
\begin{aligned}
\ddot{\sigma}_{1}= & Z_{\alpha} M_{\delta} \lambda_{1}+M_{\alpha} M_{\delta} \lambda_{2} \\
& +\left(Z_{\alpha} M_{\delta}-Z_{\delta} M_{\alpha}\right) \lambda_{4} \\
= & 0
\end{aligned}
$$

さらに , 微分後に式 (32) と (33) を用いると次のとおりと なる .

$$
\dddot{\sigma}_{1}=\left(Z_{\delta} M_{\alpha}-Z_{\alpha} M_{\delta}\right) V_{\mathrm{m}} \lambda_{3}=0
$$

式 $(34)$ は $\lambda_{3}=0$ のときに成立し, 兴のときに特異入力が 存在する.しかし, 式 (34) に含まれる $\lambda_{3}$ は, 式 $(29)$ が 示すように定数である. 光して，式 $(29)$ に示される $\nu_{3}$ は $z$ の終端拘束条件にかかる未定乗数であり， $z$ に終端拘束 が無い場合に $\nu_{3}=0$ が成立する.$z$ に終端拘束条件が無け れば, 他の状態変数はすべて初期值と終端値が等しいので, 最適解は初期状態が終端となった特殊な場合である . 一般 の初期条件が終端と異なる場合は, 式 (34) が成立せず, 特 異入力が存在しないことになる . 従って, 特異入力の存在 の可能性はあるが , 特異入力の状態の維持はできないとい える.サイドスラスタ推力も同樣の結論か薄かれ，本稿で 扱う最短時間問題は, bang-bang 入力が最適解といえる. 
3.3 数值計算例 前項で示した最短時間問題を数値的に 解き, 最適入力を求め特異入力の有無を確認する. 計算は SCGRA $^{12)}$ (Sequential Conjugate Gradient-Restoration Algorithm) で行った . 計算精度は最適性の誤差が $10^{-10}$ である . シミュレーション条件は, 高度 $30,000 \mathrm{ft}$, マッハ 数 2 で飛行する飛しょう体の初期 $z$ 座標を $7.5 \mathrm{~m}$ とした. 全長 $3 \mathrm{~m}$ の飛しょう体の重心から $0.5 \mathrm{~m}$ 前方にサイドスラ スタを配置し, ハードウエアの特性及び飛行特性を考慮し た入力の最大值は, サイドスラスタが $4 \mathrm{~g}$ を発生できる推 力, 操舵翼舵角は $20 \mathrm{deg}$ とした . 第 2 図は最大值で正規化 した入力を示している.ほぼbang-bang 入力になっている ことがわかる. 今回の解の範囲では特異入力は現れなかっ た.第 3 図は異なる初期 $z$ 座標から開始した最適解の $z$ 座 標である . 最適解の $z$ 座標は, 初期にわずかに増加してお り, 単調減少ではないことが確認できる．第 4 図は状態変 数を示している.この結果から線形近似の対象となる $\alpha, \gamma$ は微小とみなすことができる .

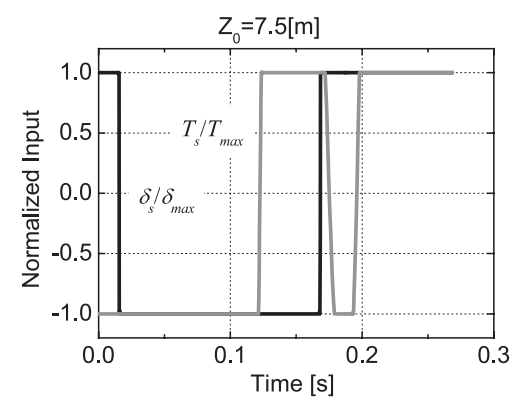

第 2 図 最適入力 (初期 $z$ 座標 $7.5[\mathrm{~m}]$ )

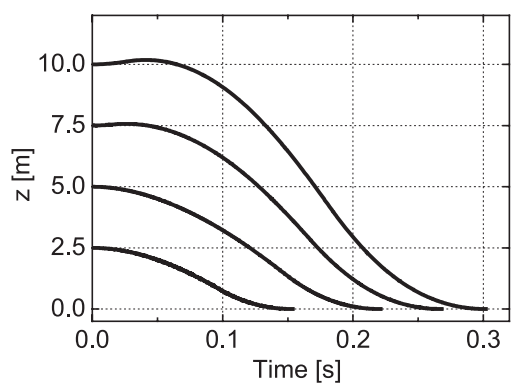

第 3 図 $z$ 座標の变化

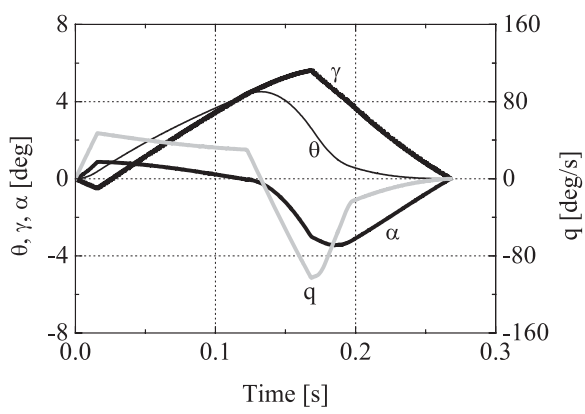

第 4 図 状態変数 (初期 $z$ 座標 $7.5[\mathrm{~m}]$ )

\section{4. 複数設計点による誘導則設計}

前章の最適解は, 繰り返し計算を行い, 時間の関数とし て最適入力を求めたものである. 異なる境界条件には新し く計算が必要となり，実装に適していない，本稿では繰り 返し計算を行わずに最短時間を解いた結果と同程度の結果 が得られる制御則を導く. 光して, 複数の境界条件を同時 最適化する複数設計点による誘導則の設計手法を提案する。

文献 13)では，終端まで単調増加する状態変数が存在し， 最適入力は滑らかに変化する系に対して誘導則か設計され ている.しかし, 本稿で扱う制御対象は単調増加する状態変 数は存在せず, 入力も bang-bang 入力である点が文献 13) と異なる。

提案する設計手法は, 切換関数をフィードバックで生成 することを特徵とする.切換関数が初期条件に対して連続 的に変化する傾向を利用し, bang-bang 入力の切換回数の 変化も柔軟に対応できる. 切換関数は, 時間の関数で与え られるフィードフォワード項と状態変数のフィードバック 項の和で与えるとする. 状態変数を $x$ とすれば, 誘導則を 次式で与える.

$$
\sigma_{i}=\sigma_{0 i}+k_{i} x \quad(i=1,2)
$$

$\sigma_{0 i}$ がフィードフォワード項であり,$k_{i}$ がフィードバック ゲインである . 添え字 $i$ はサイドスラスタ推力と操舵翼舵 角を区別している．境界条件により終端時間が異なるため， $\sigma_{0 i}$ を時間の関数で記述するには無理がある . 谷のために， 推定される終端時間で割つた無次元時間の関数として定義 する.ここで，第 3 図から初期距離と終端時間の関係を求 めると一次式で近似することで十分であることがわかる 第 5 図に关の関係を示す .このことから，推定終端時間は 次式の初期 $z$ 座標の一次関数で与える.

$$
\left(t_{\mathrm{f}}\right)_{j}=a_{\mathrm{f}}\left(Z_{0}\right)_{j}+b_{\mathrm{f}}
$$

添え字 $j$ は設計点を区別している .これにより，提案する 誘導則の切換関数はオンラインで求めることができる.

式 (23)，(24) で求められた切換関数から，光の符号のみ で入力を決めることができる.複数の境界条件を設定し, 複 数の設計点を同時に最適化すれば, フィードバックゲイン 等か数值的に求められる.ところが, 符号のみで入力を決

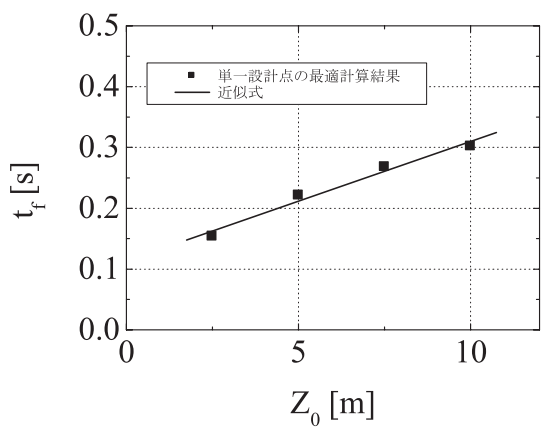

第 5 図 終端時間 
めたならば切換関数の変化に対する入力への感度が無い領 域が存在する．弚のために最適化計算が容易に実行できな い欠点がある . 本提案では，この問題点を解決するために 入力の決定に $\tan ^{-1}$ 関数を使用する.すなわち，式 (23)， (24) を次式で近似することを行う .

$$
\begin{aligned}
& \delta_{\mathrm{r}}=\delta_{\max }(2 / \pi) \tan ^{-1} \sigma_{1} \\
& T_{\mathrm{s}}=T_{\max }(2 / \pi) \tan ^{-1} \sigma_{2}
\end{aligned}
$$

これにより，上記の欠点を取り除き複数設計点による設計 が容易に実行できる. 複数の設計点に同一誘導則を適用す ると，終端状態量をすべて指定することに無理が生じ，終 端時間が長くなることが予想される . 従って , 本稿では $z$ 座標のみを指定し, 他の状態変数はぺナルティ関数として 終端誤差の最小化を狙った。

以上の議論をまとめると，誘導則の設計には以下に示す 最適制御問題を解くことになる. 2 つの設計点を使用した 例として説明する . 状態方程式は式 (9)〜 (12) を 2 組に増 やした次式の方程式になる .

$$
\left(\begin{array}{c}
\dot{x}_{1} \\
\dot{x}_{2}
\end{array}\right)=\left(\begin{array}{c}
f\left(x_{1}, u_{1}\right) \\
f\left(x_{2}, u_{2}\right)
\end{array}\right)
$$

各状態変数の初期条件は異なる.

$$
\begin{aligned}
& x_{1}(0)=\left(\gamma_{1}(0), q_{1}(0), z_{1}(0), \theta_{1}(0)\right)^{\mathrm{T}}=\left(0,0, Z_{01}, 0\right)^{\mathrm{T}} \\
& x_{2}(0)=\left(\gamma_{2}(0), q_{2}(0), z_{2}(0), \theta_{2}(0)\right)^{\mathrm{T}}=\left(0,0, Z_{02}, 0\right)^{\mathrm{T}}
\end{aligned}
$$

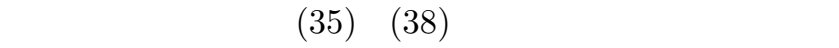
拘束条件は $z$ 座標のみにあたえられる.

$$
z_{1}\left(\left(t_{\mathrm{f}}\right)_{1}\right)=0, \quad z_{2}\left(\left(t_{\mathrm{f}}\right)_{2}\right)=0
$$

評価関数は，終端時間と状態変数の終端誤差で定義する．

$$
\begin{aligned}
J= & \sum_{j=1}^{2}\left(\left(t_{\mathrm{f}}\right)_{j}+\rho\left[\left(\gamma_{j} / \gamma_{0}\right)^{2}+\left(q_{j} / q_{0}\right)^{2}\right.\right. \\
& \left.\left.+\left(\theta_{j} / \theta_{0}\right)^{2}\right]_{\left(t_{\mathrm{f}}\right)_{j}}\right)
\end{aligned}
$$

この評価関数を最小化するフィードバックゲイン $k$ と終端 時間推定式の係数 $a_{\mathrm{f}}$ と $b_{\mathrm{f}}$, 及び，フィードフォワード関 数 $\sigma_{0}$ を数值的に求めることで誘導則か設計できる.

\section{5. 設計結果と考察}

5.1 概要 本項では, 新たに提案した手法を用いて $2 つ$ の設計点を用いて設計し, 設計点とは異なる初期条件から シミュレーションを行う. 本章では, 入力に $\tan ^{-1}$ 関数で 近似されたものを用いることにより本手法の妥当性を確認 する．ここで, 設計された誘導則の性能をみるために $z$ 座 標の終端誤差と状態変数の終端誤差の 2 種類の誤差て評価 した . 後者の終端誤差は次式で定義する .

$$
S_{\mathrm{f}}=\sum_{j=1}^{2}\left(\rho\left[\left(\gamma_{j} / \gamma_{0}\right)^{2}+\left(q_{j} / q_{0}\right)^{2}+\left(\theta_{j} / \theta_{0}\right)^{2}\right]_{\left(t_{\mathrm{f}}\right)_{j}}\right)
$$

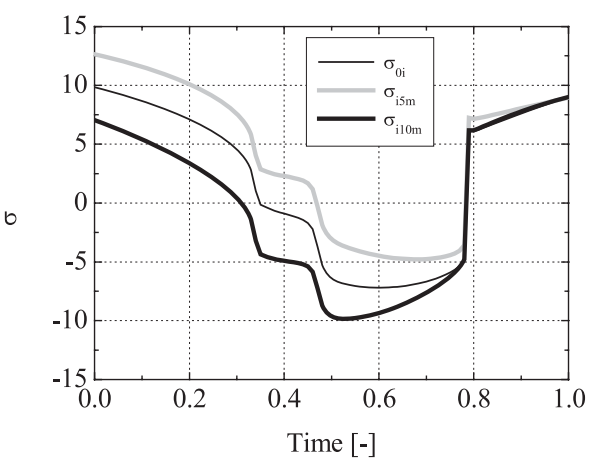

第 6 図 切替関数とフィードフォワード項

第 1 表 フィードバックゲイン (後翼操舵飛しよう体,設計点 $5 \mathrm{~m} \cdot 10 \mathrm{~m}$ )

\begin{tabular}{crl}
\hline 状態変数 & \multicolumn{2}{c}{ フィードバックゲイン } \\
\hline$\gamma$ & 0.99238 & {$[\mathrm{rad}]$} \\
$q$ & -0.57889 & {$[\mathrm{rad} / \mathrm{s}]$} \\
$\theta$ & 0.52697 & {$[\mathrm{rad}]$} \\
$z$ & 0.55925 & {$[\mathrm{~m}]$} \\
\hline
\end{tabular}

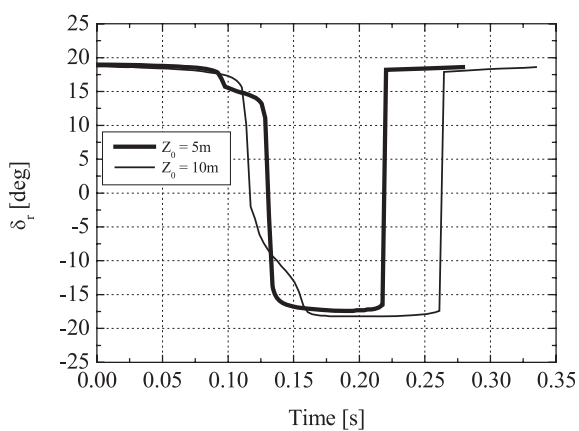

第7图 入力特性 (後翼操舵飛しよう体, 設計点 $5 \mathrm{~m} \cdot 10 \mathrm{~m}$ )

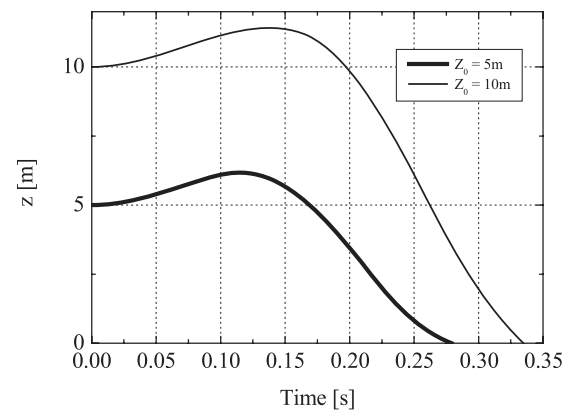

第8图 $z$ 座標の变化 (後翼操舵飛しよう体, 設計点 $5 \mathrm{~m} \cdot 10 \mathrm{~m}$ )

設計手法の妥当性を確認するために，まず，従来型の後 翼操舵飛しょう体である 1 入力系に適用する.複数条件の 最短時間問題を解き，計算されたフィードバックゲインを 用いてシミュレーションを行う. 例として設計点が $5 \mathrm{~m}$ と $10 \mathrm{~m}$ の場合で以下に示す.まず, 求めた切換関数とフィー ドフォワード項を第 6 图に示す . フィードフォワード項と 切換関数の差がフィードバックされた入力である. 第 1 表 に光のフィードバックゲインを示す．最適計算した結果を 第 7〜11 図に示す.

まず第 7 図に示すとおり，入力には，ほぼbang-bang 制 


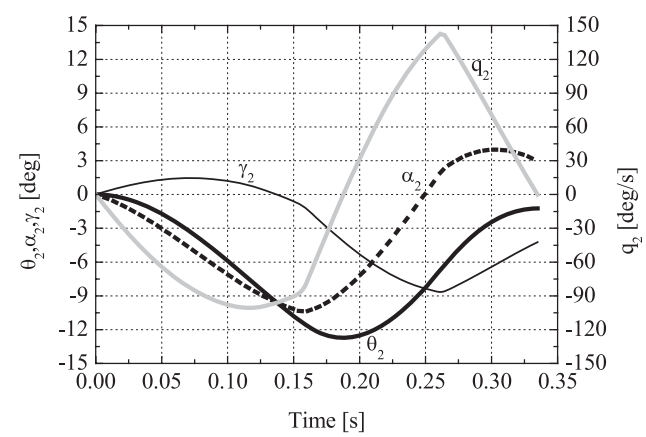

第 9 図 状態変数の変化 (後翼操舵飛しょう体, 設計点 $10 \mathrm{~m}$ )

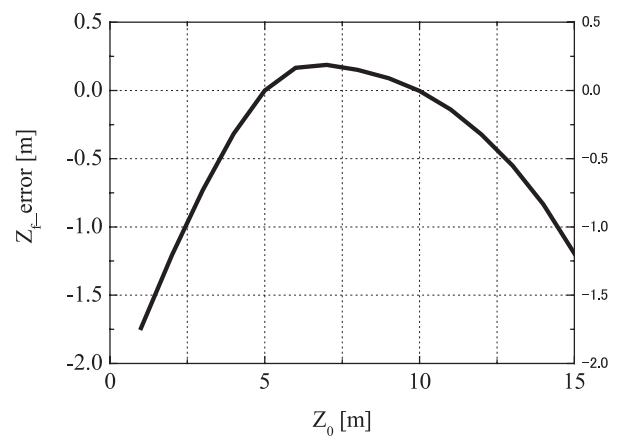

第 10 図 $z$ 座標の終端誤差 (後翼操舵飛しょう体, 設計点 $5 \mathrm{~m} \cdot 10 \mathrm{~m}$ )

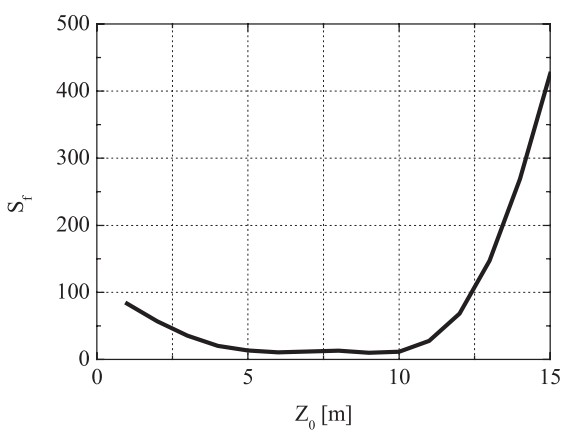

第 11 図 状態変数の終端誤差 (後翼操舵飛しょう体, 設計点 $5 \mathrm{~m} \cdot 10 \mathrm{~m}$ )

御の入力が印加されていることがわかる.第 8 図に光の移 動特性を示し，第 9 図に初期 $z$ 座標が $10 \mathrm{~m}$ の場合の状態変 数の変化を示す.移動特性については,ややオーバーシュー 卜があるが，終端において誤差がほとんど無いことがわか る. 状態変数の変化は, 終端において経路角と迎角にやや 誤差が生じているものの，ピッチレート及び姿勢角はほぼ 誤差が無いことから，よく制御されているがことがわかる． 次に複数の条件での $\mathrm{z}$ 座標の誤差と状態变数の終端誤差を 第 10 図と第 11 図に示す.

この結果から， $z$ 座標の終端誤差は, 設計点の区間から 離れるにつれて誤差が大きくなるものの, 設計点区間内で は誤差が少ないことがわかる．状態変数の終端誤差につい ても, 設計点区間から離れると誤差が大きくなるが, 設計 点区間は誤差が極めて少ないことがわかる．これらの結果 から，特定区間の初期条件からオンラインでの準最適解が 得られることがわかった .このことから本手法の妥当性が

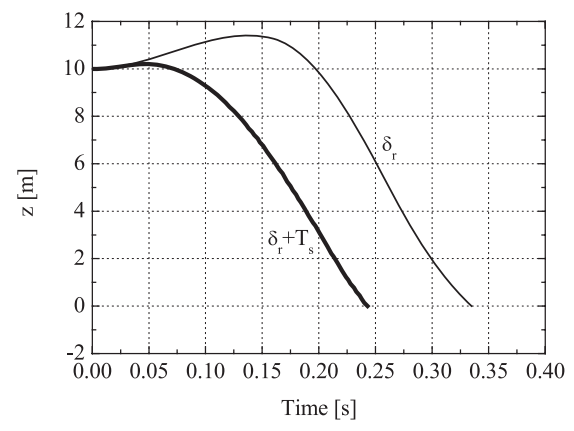

第 12 図 応答特性の比較 (設計点 $5 \mathrm{~m} \cdot 10 \mathrm{~m}$ )

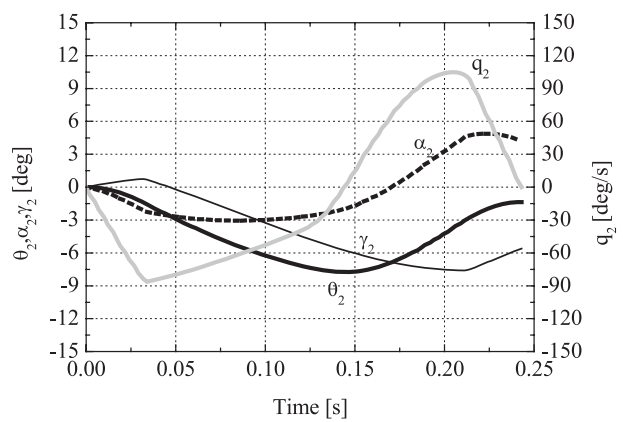

第 13 図 状態变数 (サイドスラスタ搭載飛しょう体, $Z_{0}=10 \mathrm{~m}$ )

確認された .

5.2 後翼操舵飛しょう体モデルとサイドスラスタ搭載モ デルとの比較 本研究はマヌーバな運動に有効に作用する サイドスラスタを搭載した飛しょう体の研究を行っている． このサイドスラスタの有効性を検証するために, 前項まで で検証された本提案の手法を，従来型の後翼操舵飛しょう 体とサイドスラスタ搭載飛しょう体の 2 つに適用し, シミュ レーションを行い比較検討する．まず，後翼操舵飛しょう 体モデルとサイドスラスタ搭載飛しょう体モデルの最短時 間を比較するために応答特性を見てみる．ここでは，例と して設計点が $5 \mathrm{~m}$ と $10 \mathrm{~m}$ で最適計算をした場合で述べる. その結果を第 12 図に示す.この結果からサイドスラスタを 使用することにより，後翼操舵のみよりも最短時間が短縮 され，オーバーシュートも少なく良好に制御されているこ とがわかる .これは第 3 図の $10 \mathrm{~m}$ のケースと比べるとほ とんどの区間で一致している．つまり，ほとんどの区間で 最適解が得られているといえる．

弚のときの， $Z_{0}$ が $10 \mathrm{~m}$ の場合のサイドスラスタ搭載飛 しょう体の状態変数を第 13 図に示す.第 9 図と比較すると 終端に少し誤差があるものの, 全体的に変動が少なくなつ ており, 後翼操舵飛しょう体に比へ安定して飛行している といえる．このことからサイドスラスタを使用し，本手法 によるフィードバック制御をすることで, オーバーシュー トが少なく，より短時間で所望の位置へ制御することがで きることがわかった .

5.3 設計点による影響 本項では, サイドスラスタ搭 載飛しょう体で，より現実的な使用を考え設計点の影響を 検証する。なお，本稿で扱う最短時間軌道变更問題は，初 


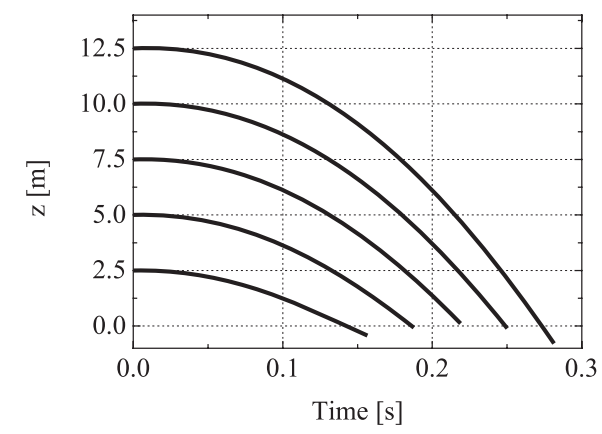

第14図 $z$ 座標の変化 (サイドスラスタ搭載飛しょう体)

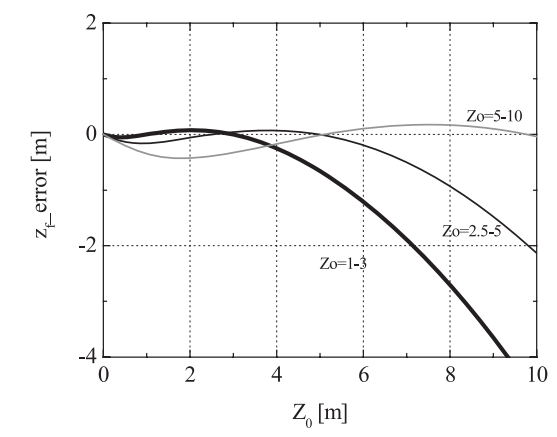

第 15 図 $z$ 座標の終端誤差 (サイドスラスタ搭載飛しょう体)

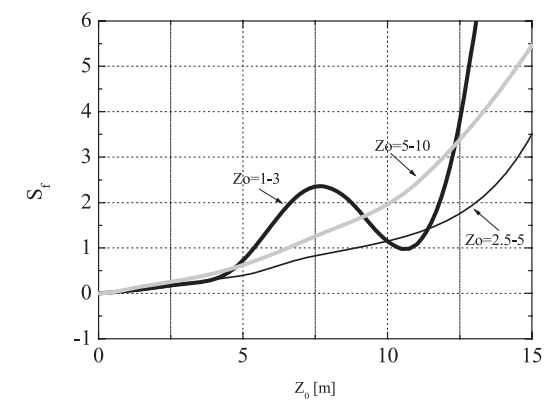

第 16 図 状態变数の終端誤差 (サイドスラスタ搭載飛しょう体)

期状態量が終端状態と等しい場合には, 入力が 0 となる . すなわち, 初期 $z$ 座標が $0 \mathrm{~m}$ の場合には 2 入力とも 0 とす る誘導が最適である. 初期 $z$ 座標が $0 \mathrm{~m}$ の場合は, フィー ドフォワード項も 0 にする必要がある. 初期 $z$ 座標が 0 の 場合も設計点の一例として適用できる設計手法か望ましい． 以下に示す数值計算例では, $\sigma_{0 i}$ を除いてフィードバック のみで誘導則を設計している。

シミュレーション条件は, 飛しょう体の現実的なマヌー バを考慮し，(1) 設計点が $5 \mathrm{~m}$ と $10 \mathrm{~m}$, (2) $2.5 \mathrm{~m}$ と $5 \mathrm{~m}$, (3) $1 \mathrm{~m}$ と $3 \mathrm{~m}$ の場合の 3 つの設計条件で計算し制御系を構築 し，任意の初期距離 $Z_{0}$ を設定しシミュレーションを行っ た . 例として(1)の設計条件の結果を第 14 図に示す. 第 3 図 と比較すると, 単体て繰り返し計算をした結果と本手法に よる計算は，ほぼ同樣な結果が得られた .この終端の誤差 をプロットしたのが第 15 図である.第 16 図は設計条件ご との状態变数の終端誤差を示す．
この結果から $z$ 座標の終端誤差は, 各設計点区間から離 れると誤差が大きくなるが, 設計点近傍ではほぼ誤差が無 く，また $Z_{0}=0$ から設計点の区間は誤差が少なく，良好 な結果が得られていることがわかる.第 16 図から，状態 変数の終端誤差は $Z_{0}=2.5 \sim 5 \mathrm{~m}$ の方が良好になっている が, 評価関数は両者の和である. 第 15 图より $5 \sim 10 \mathrm{~m}$ で 設計したものが良好になっている.これらのことから設計 点を絞ることにより，良好な結果が得られことがわかった．

\section{6. 結論}

本稿では，実際の飛しょう体に適応可能な制御系として， 複数条件を最適化し，切換関数をフィードバックで生成す る誘導制御系設計を提案した . まず特異入力の存在の可能 性を示し，弚の維持が困難であると導き, bang-bang 入力 が最適入力であるとした，乥れを踏まえて，提案した新た な設計手法の有効性を示し, 本研究の特徵であるサイドス ラスタを使用した制御系の設計を行い，妥当性を確認した。 この飛しょう体システムに本研究の提案した手法を導入す ることにより，終端位置を任意に変えることにより，比較 的簡単に複数設計点の最適設計ができることか確認できた .

\section{参 考 文 献}

1) Imado, F. and Kuroda, T.: Optimal Midcourse Guidance for Medium-Range Air-to-Air Missiles, Proceedings of AIAA Guidance, Navigation and Control Conference, Minneapolis, MN, 1988, pp. 100-108.

2) Imado, F. and Kuroda, T.: Optimal Thrust Control of a Missile with a Pulse Motor, J. Guid. Control Dynam., 14 (1991), pp. $377-382$.

3) 木下拓也, 今度史昭 : UAV フライト・シミュレータの開発と光 の応用, 日本航空宇宙学会論文集, 55 (2007), pp. 309-317.

4) Lichtsinder, A.: Minimum-Time Maneuvers of ThrustVectored Aircraft, J. Guid. Control Dynam., 21 (1998), pp. $244-250$.

5) Wise, K. A.: Bank-to-Turn Missile Autopilot Design Using Loop Transfer Recovery, J. Guid. Control Dynam., 13 (1990), pp. 145-152.

6) Tournes, C., Shtessel, Y. and Shkolnikov, I.: Autopilot for Missiles Steered by Aerodynamic Lift and Divert Thrusters Using Nonlinear Dynamic Sliding Manifolds, Proceedings of AIAA Guidance, Navigation, and Control Conference and Exhibit, 2005, San Francisco, CA, AIAA Paper 2005-6382.

7) Mracek, C. P. and Ridgely, D. B.: Missile Longitudinal Autopilots: Connections between Optimal Control and Classical Topologies, Proceedings of AIAA Guidance, Navigation, and Control Conference and Exhibit, 2005, San Francisco, CA, AIAA Paper 2005-6381.

8) 越智徳昌：双翼操舵飛翔体の垂直加速度及び迎角制御系の設計, 日本航空宇宙学会論文集，51 (2003), pp. 621-627.

9) 江口弘文 : 誘導制御系の設計, 東京電機大学出版局, 東京, 2005, pp. $153-161$.

10) 加藤寛一郎: 工学的最適制御, 東京大学出版会, 東京, 1993, pp. 133-135.

11) Bryson, A. E. and Ho, Y. C.: Applied Optimal Control , John Wiley \& Sons, New York, 1975, pp. 108-117.

12) Miele, A., Cloutier, J. R., Mohanty, B. P. and Wu, A. K.: Sequential Conjugate Gradient-Restoration Algorithm for Optimal Control Problems with Nondifferential Constrains, Part I, Int. J. Control, 29 (1979), pp. 189-211.

13）上野誠也 : フィードバック誘導制御則による航空機の最短時間旋 回 , 日本航空宇宙学会誌 , 45 (1997), pp. 29-35. 